\title{
THE SENSE OF BELONGING: HYBRID OR REINVENTION? A STUDY OF K. S. MANIAM'S IN A FAR COUNTRY
}

\author{
Zanyar Kareem Abdul \\ Department of English, University of Charmo, Iraq. \\ E-mail: zanyar.kareem@charmouniversity.org
}

Received: 2021-04-26

Accepted: 2021-06-03

\begin{abstract}
The issue of race, identity, and multiculturalism are focal points in modern novels. K. S. Maniam, as an Indian-Malaysian as such, explains the same question again in his writings. There is a longing or rather a forlorn look at India as the Motherland of some of the Indians in Malaysia in the setting of $\mathrm{K}$. S. Maniam's stories. The novel does not provide a complete recovery of the original country; it is instead giving a deep insight into finding out a connection to the place one settles in. In a Far Country is a typical example of the modern chaotic world through which Maniam sheds light on it. The research aims to analyse the redefinition of identity and determining race. It is also to explore the choices between a native and nonnative value in a foreign land. Under the analysis, Homi Bahbah's theory of hybridity is chosen for the study of the novel. It is a significant and difficult step at the same time to reinvent one's identity through a hybrid culture or rather to be called "reinvented" when the final solution fails and instead "reinvention" shapes a new identity.
\end{abstract}

Keywords: race, land, multicultural, identity, India, postcolonialism

\section{Introduction}

The twentieth century can bear witness that there is much ethnic consciousness that voices out loudly through many speeches, writings, and words. The conflict is seen through sharing one's pure ethnicity and spreading the message around the world. The changes in social, historical, and geographical ones have raised the questions of race, identity and cultures all around the world. Some writers like V.S. Naipaul, Toni Morrison, Bharati Mukerjee and K.S. Maniam are among those who denote many voices from many different cultures. There is one common feature among these fiction pundits that they have a nationality for a country that is as alien to their motherland. The common themes that these diasporic writers share include migration, displacement, and hybridity. K.S. Maniam is born in Kedah, West Malaysia, in 1942. He started writing poetry in the early 60s and 70s, short stories and novels. He was rewarded Raja Rao Award for his fabulous contribution to the literature of the South Asia Diaspora in New Delhi in 2000. Maniam's major concerns deal with postcolonial theory, especially British colonialism as it is seen in his first novel, The Return (1981). Maniam is not distracted by his rivalry fellowships as they believed it is a failure to give an Indian perception concerning drawing Malaysian's attention. Yet, however, Maniam assures readers that writing works best when the worldview of a writer is shaped by the time and place in which his awareness arose again and brings bitter reality into fiction. Mixing different characters as to show Malaysian multicultural country is at one side, the 
misunderstanding of the term "multiculturalism" is on the other side of the bridge where the two must fight for the final call. So, the reader is allowed to create his own place where he can imagine as a part of a multicultural society. Nelson (1992) has confirmed the "haunting presence of India" is at the heart of diasporic novelists with "anguish of personal loss" that Indian writers have been writing on, from this alienation, despair, and displacement, etc. comes to mind without being forced. Maniam's preference of dynamic and multi-faceted Malaysian society is argued in the hope of finding "self" in words and/or "voice" among others with accepting or refusing its consequences. Ravi in The Return has the same issues differentiating between the mother-land or the land as he himself sees it as guest, Peter Wicks in his article "Diaspora and identity in the fiction of K. S. Maniam" (1994) observes India as a "place of memory and nostalgia" and much of the plot constitutes a "hymn to Indian ethnicity". The question is Maniam cannot answer what if someone is unable to escape from the diaspora, and from its consequences? The perception looks simple, yet if it comes to a solution; Maniam and his own characters are stuck and the unresolved issues remain as they are or left, on purpose, for the readers.

\section{Literature Review}

Maniam has to mix myth, history, past and present. A lot of critics put much credence in the novel in which it revolves around the notes, letters, meditations and memories of Rajan, a middle-aged businessman. His reflections are detected from his past, thus embarking on a journey to the far country of his imagination. Rajan, Indian and the protagonist of the novel, has much more to tell the readers: being away from one's real land costs a lot in terms of thinking, and childhood memories are going to destroy one's life compared to the owner of the land, Malay. Importantly, Maniam is a Malaysian, and the novel is to be trying to become a Malaysian. The sense of being and becoming is bitterly in the core of the discussion in the novel. Rajan is a successful businessman in a country marked by ethnic division. Accompanied by Lee Shin and Zulkifli in quest of the spirit of the land, Rajan's nonstop questioning on a real land is boomed throughout the story. Numerous questions are coming out of Rajan's mind in terms of cultural roots, identity and race issues. Thus he sees himself as a protagonist and a victim at the same time to find answers. Malaysia is a colonized country taken by the Portuguese, Japan and Finally Britain which led to its victory and Independence in 1957. The significant shift that appears in the colonial history of Malaysia's population with three different races: Malay, Chinese and Indian, through which Maniam's eagerness can be detected over his real land.

Since then, Malay took political power and his elite both traditional rulers and modern ones announce their race as number one and as "sons of the soil". Since the majority of Malays were farmers and fisher folk; they enunciated the power of their language attached to their land. So, the Malay language is the national language for all. Maniam's niftiness in organizing the structure of the novel is depicted, especially in creating the characters; for instance, Pak Zul is given that power relating to his strong attachment to the land. Sharrad describes the novel as "remarkable for its experiment. It moves beyond early Malayan writing in English, which sought to establish a local literary imagination in opposition to an imposed colonial one." (xv, 1993). In A Far Country searches for both moments: from a village to a town associated with racial harmony, but they are both sensitive and fragile.

Rajan, in In a Far Country, seeks attentively to redefine Malay-defined Malaysia, or in his own words "some elusive rootedness", not knowing unconsciously he is the one who stands the concept itself. Being an "observer" is what he is in reality, rather than a national folk 
mixing in the society, "the idea that nothing of me will ever remain" is still hideous. Instead, the novel "offers another return to Hindu verities in the quest for a mystical light that is beyond and above all earthly existence and travail." (Wicks, 2002) The adaptation of the homeland and the land they live on creates a sense of belonging. Having said that, Becker and Bhugra (2005) assert that migration is thus accountable for losses that go beyond the loss of one's birthplace, namely "the loss of one's social structure and culture". Thus, this confuses is to whether welcomes the new homeland or the one attached with his own. It is an inevitable experience where Maniam's characters prevail in their family life. In Bahbah's term "in-between" is the one each character must live, either in the homeland or in an adopted land. The choice is theirs. In either case, psychological and physical frustration are deemed as they suffer each day and each time as the word "unhomliness" arrives at the gate and takes its journey throughout the novel.

\section{Research Method}

The paper is a qualitative research about the protagonist in In a Far Country in relation to the postcolonial theory; it is a hero-research study in which he is analysed thoroughly. The study also presents some of the significant quotations of Homi Bahbah in investigating the needs and demands of the characters through which race issue is inevitable: the journey is taking place from Malay, Chinese and an Indian chap where he doubts his existence. The result denotes how the issue of racisim is affecting each individual and finding a spot to be in an exile.

\section{Results and Discussion}

Manima's The Return (1981) and In a Far Country (1993) both reveal the suffering of Indians bringing their culture to the new world. Maniam emphasizes the disconnection between one's real culture and identity into a different one; it is something that cannot be harmonized. These two novels show an immigrant community living in Malaysia before and after Independence. The Return (1981) is about an immigrant family who tries to mingle themselves with the current land. The protagonist, Ravi, faced a lot of crises in determining his own identity, believing that studying at an English school might adapt to the situation. As a result, he sees a vast difference between western and his own culture. Maniam's first sharp criticism is on the culture of British which influenced Ravi in picking up the English culture so fast and distancing him from his own,

I had felt I was the least important person in the gathering. I could have been age-old pebble, confirmed in its existence only because they had discovered it. Murugesu's presence, the incense curling towards the smoke-glazed pictures of the gods and goddesses, joss-sticks stuck into spotted bananas, had seemed the surface of ancient, terrestrial darkness. There was no unexpectedness. I was expected and accepted. Miss Nancy made me feel I was a discovery in myself (Maniam 1981: 30).

K. S. Maniam, in his article, In Search of a Centre states that Ravi's life may bear resemblance to his own "but they are only resemblances" (Maniam 1993: par.22). Maniam had also studied in England to become a teacher. Nevertheless, Maniam confirmed that in his adolescent years, he was strongly influenced by Western culture. No sense of belonging once one attended the English school. What Rajan tries to do is stabilize his mental trauma 

Abdul

through his successful business; failure to do so, he recalls childhood memories and those characters he had met when he was young. He avoids meeting people in his current days.

As far as I recall there had been only one great adventure in his life - his escape from India to Malaysia. There were times when he muttered and mumbled during his toddy-soaked carelessness, and it was through these moments of indiscretion that his story came through to me. Thinking back, I realized that that was how he tried to pull himself out of his limp helplessness. (Maniam, 1993: 4)

Homi Bahbah focuses on the term "hybridity" which is widely used in postcolonial theory, which refers to "the creation of new transcultural forms within the contact zone produced by colonization." (Ashcroft, Griffiths, Tiffin, 1998:118). Hybridization can also be explained in terms of politics, culture, and linguistics. The term is used by Bakhtin and his idea that it "destabilizes univocal forms of authority". However, Bahbah believes, hybridity is a backbone to show the relationship between the colonised and the coloniser and their independence. Besides, he asserts that all cultural statements and systems are constructed within a space as it is so-called "Third Space of enunciation".

What makes cultural identity is its contradiction and in ambivalent space and for him "the recognition of this ambivalent space of cultural identity may help us to overcome the exoticism of cultural diversity" in which it empowers hybridity of which cultural difference operates, "it is significant that the productive capacities of this Third Space have a colonial and postcolonial provenance. For a willingness to descend into that alien territory may open the way to conceptualizing an international culture, based not on the exoticism of multiculturalism or the diversity of cultures, but on the inscription and articulation of culture's hybridity." (Bahbah, 1999 : 38). It is the "in-between" space that carries the burden and meaning of culture, and this is the reason behind the crucial significance of hybridity. Inbetween is also a fundamental key-idea in Bahbah's writing, "Border lives; the art of the present" the essay in which he clarifies those who live "border lives" on the margins of very different nations. To live at the border, according to Bahbah, demands a new "art of the present" that relies on having the contrary logic of the border, and reuse the ways in which one presents things such as identity, community, and history. However, borders are crucial while having contradiction and ambivalence as they are separated.

There are locations where one moves beyond a barrier, Bahbah defines that "beyond" is an in-between site of transition: "the beyond is neither a new horizon, nor a leaving behind of the past....we find ourselves in that moment of transit where space and time cross to produce complex figures of difference and identity, past and present, inside and outside, inclusion and exclusion". The space of the "beyond" is stated as in-between sense: for example, "liminal" or "hybrid". Furthermore, Bahbah denotes the significance of the inbetween spaces by confirming "these 'in- between' spaces provide the terrain of elaborating strategies of selfhood- singular or communal- that initiate new signs of identity" (Bahbah, 1999:1). This leads to giving a summary of Bahbah's point of view: first, he is against essentialist subject or the idea of "sovereign", since identity is a discursive product. Second, to remake subjectivity is possible as it is a discursive product. Thirdly, the "new" signs of identity had a great influence on the individual and the group as well. The process of decolonization entails a sense of 'in-betweeness', it is clarified in detail in Homi Bahbah's book, where colonised people do not know their origins, a moment of confusion. Tyson calls this feeling "unhomeliness", a term originally belongs to Bahbah, which means a "feeling of 
being caught between cultures, of belonging to neither rather than to both. . . . To be unhomed is to feel not at home even in your own home because you are not at home in yourself: your cultural identity crisis had made you a psychological refugee, so to speak" (Tyson, 2006: 421). Since the old colonized identity no longer existed, a new form of identity is to be created which leads to another phase called, according to Bahbah's, hybrid. The destruction of identity is a common feature that happens to colonised people, so a lot of postcolonial communities look at history in the hope of the reestablishment of authentic identity. Said in Culture and Imperialism mentions post-colonial writers:

bear their past within them-as scars of humiliating wounds, as instigation for different practices, as potentially revised visions of the past tending toward a post-colonial future, as urgently reinterpretable and redeployable experiences, in which the formerly silent native speaks and acts on territory reclaimed as part of a general movement of resistance, from the colonist (Said, 1993:212).

So, one can interpret Rajan's confusion as the result of lacking his own culture, Indian culture, plus his overthinking on the past make him an empty person through which his identity becomes zero, admitting "I thought I would find heaven. But people can be wrong. A man can be wrong. The price has to be paid. I am paying it with blood... Why must there be suffering? We suffered there in India. Now there is only suffering. No escape like the last time." $(1993,7)$ Rajan's suffering is to that extend, readers can envisage what happens in Malaysia. In Malaysia, political and social power, including the Malay language, are controllable; it makes it rather challenging to establish the identity by the minority. So, Maniam wants to make that effort in redefining the identity and cultural background of Indian people; he is straightforward in stating that writing about the Indian community in Malaysia "was not a blind loyalty to my own race; rather it was writing about a community which breathed closest to my heart" (Maniam 1993: 21).

Another instance is paced out in the novel of what the early Indian settlers went through in Malaysia after leaving their motherland. Maniam successfully depicts how Indians struggled in the new land through the flashbacks of Rajan:

Those stars were wrong to bring us here. But how can we stop ourselves from following their pull? Everything is joined together. One land's grass dies, another land's jungle is cool and full of fruits. Like blind bats we come to the fruit trees. There we're caught in the net (Maniam, 1993: 6).

Rajan is defined by as a "house and property owner, with a solid bank account" (47) leaving everything behind. He remains at a room where no desires to meet or go out, and obsessed with his inner thoughts. There is a return to Hindu integrity demanding for a mystical light which is beyond every earthly existence, asserting:

I see the light. It is the light of pure living. It is there shining all around and into me. There is no ego, no self-interest, no loyalty to all the people. I've known; only the desire to contain that light within me and to take it out into the world. For it is the light of intelligence, not the darkness of the limited mind. (48)

In this case, Rajan in In A Far Country and Naina in The Return both share the same path to turn from worldly success to spiritual enlightenment. At the beginning, Rajan keeps 

Abdul

himself shut in a bright room to begin thinking about what goes around him in terms of soil, race and his lost identity. It is both crucially significant and his reconciliation with his wife at the end of the novel; what is so-called a step from total darkness to its light.

Flashbacks and dreams work stunningly throughout the novel in which one day Zulkifli (Malay) takes Rajan to the jungle to show him the real land. A place where they are supposed to look for a tiger, and during the break Rajan falls asleep and dreams. The instance is the most pivotal part in the story wherein the vision Rajan is not a human except a chameleon. Zulkifli sees the tiger, but Rajan is unable to do so; failing to feel its existence. Zulkifli explains the reason why Rajan does not see it due to not having ancestors in Malaysia. (Maniam, 1993: 101). Through this, Rajan is continuously reminded that he is not the son of the soil. Maniam's use of symbolism here is very accurate; tiger represents "sons of the soil", and the jungle is a sign of "motherland", with the chameleon which stands for "immigrant". Rajan finishes the whole journey without seeing the tiger. He does not feel the landscape, and it cannot be forced, he thought; no invitation is received from the jungle; instead the total rejection and repulsion are presentable. The tree spot represents the gateway to the land, Zulkifli says "Once we cross over, we change." (95) as an indirect sign that one dares to face the native land and thus, one is connected to the land as reminded by Zulkifli to forget the past, otherwise, no way to step forward. Maniam wants to unravel the truth that this political diagram and alien culture cannot be digested and accepted as he finally admits,

I consciously threw that background I was born into, overboard? I recall now that I ran away from my parents'- especially my father's-background and history. I remember ironically now, expunging my memory of them. Yet when I use memory now there seems to be nothing in it. Only a blank. (Maniam, 1993: 136)

Rajan is successful in his business, but puzzling on his own identity and origin is an obstacle. Obsession thereupon becomes a nightmare. He looks happy in leaving his father's background and digs into his future. His mind goes blank and devoid his memories of his ancestors. He tries to reconcile with the host land with his empty mind and a new identity, saying:

I've given up resistance. It was resistance that had prevented me from entering the depths of tiger-land that Zulkifli had promised me. It has taken me so many years to stop running that I don't mind waiting for as long as is necessary. (Maniam, 1993: 138)

Rajan is in a dilemma and stuck between accepting the past and merging with the new Malaysian culture forming a new identity. It is difficult for a third-generation Indian like Rajan to take that in postcolonial Malaysia. Maniam leaves the confusion/tension as it is without providing Rajan's approval in merging and accepting a new identity with his alien culture.

\section{Conclusion}

Maniam's In a Far Country is not a story of the author alone; it involves a lot of immigrants around the world. He shares what he feels about not belonging to the real land with others and the readers. Many people have lived in an adopted country a long time ago, but have to realize at the end, the feeling of being uninvited guests. So, it has to be admitted 
it is inevitable when one wants to write about homeland, race, and identity. Thus, their outloud voice and anger can be spread through literature. The power of the text lies in its myriad people and painful record of the third Indian Malaysian generation in providing a rendezvous with their own identity in an alien country. Rajan is bewildered in making the final decision, he may do so, but consequences await him at the end of the road. To be Malaysian Indian, or not to be is a significant question through the voice of Rajan; it is a universal question for the Indians living abroad, but it is surprising for others who live in their homelands. V. S. Naipaul affirms, "To be an Indian or East Indian from the West Indies is to be a perpetual surprise to people outside the region." (1972: 33)

Maniam's poets, short stories, and novels are the places of telling the world about their suffering. Words become a magical tool that subsists in the literary works which explore and expose unsaid words; a step forward to look or search for a greener place, a place can be called Motherland.

\section{References}

Ashcroft, Bill, Gareth Griffiths, and Helen Tiffin. (1998). Post-Colonial Studies: The Key Concepts. London: Routledge.

Bahbah, K. Homi, ed. (1999). Nations and Narration [C]. New York: Routledge. . (1994). The Location of Culture. New York: Routledge.

Becker, M. A. and Bhugra, D. (2005). Migration, cultural bereavement and cultural identity.

Maniam, K.S. (1981). The Return. London: Skoob Books Ltd.

Maniam, K.S. (1993). In a Far Country. London: Skoob Books Ltd.

Maniam, K.S. (April 1994). In Search of a Centre. Retrieved 17 Juli 2012. http://www.ucalgary.ca/uofc/eduweb/engl392/maniam-cent.html.

Naipaul, V. S. (1972). The Overcrowded Barracoon and Other Articles. London: Andre Deutsch.

Nelson, E.S., ed. (1992). Reworlding: The Literature of the Indian Diaspora. New York: Greenwood.

Said, W. Edward. (1993). Culture and Imperialism. London: Vintage. Print. . (1978). Orientalism. London: Penguin.

Sharrad, Paul. (1993). Introduction. In a Far Country. K. S. Maniam. London: Skoob Books Publishing Ltd.

Tyson, Lois. (2006). Critical Theory Today: A User Friendly Guide [M]. New York: Routledge. Wicks, Peter (2002). Diaspora and Identity in the Fiction of K. S. Maniam. 3 (4), 115-127. 